\title{
PERANGREEN TRUST MEMEDIASI PENGARUH GREEN PERCEIVED VALUE TERHADAP GREEN PURCHASE INTENTIONS
}

\section{Ni Luh Putu Martha Pradnyadewi ${ }^{1}$ I Gde Ketut Warmika ${ }^{2}$}

\author{
${ }^{1,2}$ Fakultas Ekonomi dan Bisnis Universitas Udayana (Unud), Bali, Indonesia \\ E-mail: marthapradnya@gmail.com
}

\begin{abstract}
ABSTRAK
Penelitian ini bertujuan untuk mengetahui pengaruh green perceived value terhadap green trust dan green purchase intentions, pengaruh green trust terhadap green purchase intentions serta peran green trust memediasi pengaruh green perceived value terhadap green purchase intentions produk Tumbler Starbucks On the Go di KotaDenpasar. Penelitian dilakukan pada produk Tumbler Starbuck On The Go di Kota Denpasar dengan jumlah responden sebanyak 100 responden. Jumlah responden ditentukan menggunakan metode purposive sampling, yaitu teknik penentuan sampel dengan pertimbangan tertentu. Data diperoleh dengan menyebarkan kuesioner yang dianalisis menggunakan teknik analisis jalur (path analysis) dan uji Sobel. Hasil pengujian dari green perceived value secara positif dan signifikan berpengaruh terhadap green trust dan green purchase intentions produk Tumbler Starbuck On The Go di Kota Denpasar. Green trust mampu memediasi pengaruh green perceived value secara positif dan signifikan terhadap green purchase intentions.
\end{abstract}

Kata kunci:green perceived value, green trust, green purchase intentions

\begin{abstract}
This study aimed to determine the effect of perceived value to the green green trust and purchase intentions green, green influence trusts to purchase green green intentions and the role of trust mediating effect of perceived value of green against green product purchase intentions Tumbler Starbucks On the Go in Denpasar. The study was conducted on the product Tumbler Starbucks On The Go in Denpasar with the number of respondents was 100 respondents. The number of respondents was determined using purposive sampling method, which is the technique of determining samples with certain considerations. Data obtained by distributing questionnaires were analyzed using path analysis (path analysis) and Sobel test. The test results of green perceived value in a positive and significant effect on trust and green green product purchase intentions Tumbler Starbucks On The Go in Denpasar. Green trust is able to mediate the influence of green perceived values positively and significantly on green purchase intentions.
\end{abstract}

Keywords: green perceived value, green trust, green purchase intentions 


\section{PENDAHULUAN}

Isu mengenai lingkungan menjadi perhatian penting bagi masyarakat di berbagai belahan dunia. Kemajuan teknologi dan globalisasi tidak dapat dipungkiri memberikan berbagai dampak terhadap lingkungan. Salah satu dampak dari perkembangan teknologi adlah pencemaran plastik. Sehingga akhir - akhir ini kesadaran masyarakat untuk menjaga lingkungan dari pencemaran plastik semakin meningkat.

Beberapa bukti tentang dampak dari perkembangan teknologi yang ditunjukkan oleh para ilmuan dan pemerhati lingkungan terkait dengan hal ini misalnya penipisan lapisan ozon, pemanasan global yang berdampak pada perubahan iklim dunia, perkembangan penyakit yang membahayakan tubuh akibat dari penggunaan bahan - bahan kimia sintetis pada makanan, serta polusi udara dan air yang diakibatkan dari penggunaan bahan - bahan kimia yang dapat membahayakan kelangsungan hidup dari manusia dan lingkungannya (Putri dkk., 2014).

Pencemaran lingkungan tersebut kemudian menjadi tantangan tersendiri bagi perusahaan untuk mewujudkan produk ramah lingkungan. Secara tidak langsung perusahaan juga mengedukasi konsumen untuk mewujudkan kesadaran masyarakat untuk menjaga lingkungan dengan membeli produk ramah lingkungan. Salah satu cara perusahaan untuk mengedukasi konsumen tersebut dengan mempengaruhi konsumen sehingga melakukan keputusan pembelian produk ramah lingkungan. Istilah yang dilakukan pemasar ini adalah pemasaran hijau atau green marketing.Green marketing adalahkonsistensi dari semua 
aktifitas yang mendesain pelayanan dan fasilitas bagi kepuasan kebutuhan dan keinginan manusia, dengan tidak menimbulkan dampak pada lingkungan alam (Balawera, 2013). Pemasar dewasa ini harus memiliki tanggung jawab atas pengaruh - pengaruh sosial dan lingkungan akibat tindakan mereka, di masa mendatang perusahaan di haruskan mematuhi standar yang semakin tinggi atas tanggung jawab lingkungan dari aktivitas pemasaran dan pabrik mereka (Kotler and Armstrong, 2006: 36).

Tren pemasaran hijau merujuk pada kepuasan kebutuhan, keinginan dan hasrat pelanggan dalam hubungan pemeliharaan dan kelestarian lingkungan (Cherian dan Jacob, 2012). Konsumen tentu ingin memiliki peran dalam pelestarian lingkungan. Peran tersebut dapat dilakukan konsumen melalui sikapnya dalam melakukan keputusan pembelian produk. Namun sebelum melakukan keputusan pembelian produk tentu konsumen harus memiliki niat pembelian akan produk tersebut. Sehingga perusahaan sendiri tentu perlu menciptakan persepsi nilai akan produknya sehingga timbul kepercayaan pada konsumen dimana diharapkan akan timbul niat pembelian produk.

Green purchase intentions adalah niat untuk membeliproduk atau merek yang kurang berbahaya lingkungan (Rizwan et al., 2014).Niat beli hijau adalah proses tentang apa yang akan ditentukan konsumen untuk menentukan pilihan agar tidak merusak lingkungan dari berbagaialternatif yang ada (Ariyanti dan Iriyani, 2014).Sebelum konsumen menggunakan suatu produk yang akan dibelinya, konsumen cenderung mengandalkan informasi dari orang lain yang terlebih dahulu menggunakan produk tersebut, lalu Informasi yang ditangkap oleh 
stimulus seseorang akan mempengaruhi persepsi nilai akan suatu produk yang berniat dibelinya (Wulandari dan Ekawati, 2015).

Persepsi didefinisikan sebagai sebuah proses yang dilalui seseorang individu untuk memilih, mengorganisasi, dan menginterpretasikan stimuli ke dalam sebuah gambaran tentang dunia, yang memiliki arti atau makna yang bersifat koheren (Suprapti, 2010: 68). Green perceived value sendiri diartikan sebagai keuntungan bersih dari penilaian keseluruhan konsumen melalui evaluasi suatu produk atau jasa (Liang \& Chaipoopirutana, 2014). Green perceived value sebagai penilaian menyeluruh konsumen terhadap seluruh manfaat yang akan diterima dan apa yang akan dikorbankan berdasarkan pada hasrat mengenai lingkungan (Chen and Chang, 2012). Jadi Green perceived value sendiri merupakan bentuk dari penilaian konsumen terhadap suatu produk yang mampu memberikan dampak positif terhadap lingkungan.

Ketika perusahaan sendiri mampu mempertahankan kepercayaan konsumen maka akan timbul persepsi nilai dari konsumen yang diharapkan akan mempengaruhi niat beli konsumen sendiri. Pada konsep green trust sendiri terdapat kata 'trust' yang memiliki arti 'kepercayaan', kepercayaan merupakan hal yang penting untuk dibangun dan dijaga oleh perusahaan guna mempertahankan hubungannya dengan konsumen (Mahendra dan Sulistyawati, 2017). Kepercayaan konsumen adalah semua pengetahuan yang dimiliki oleh konsumen dan semua kesimpulan yang dibuat konsumen tentang obyek, atribut, dan manfaatnya (Efriandi, 2013). Green trust adalah sebuah kehendak untuk bergantung pada suatu produk, jasa, atau merek, atas dasar keyakinan atau 
harapan yang dihasilkan dari kredibilitas, perbuatan baik, dan kecakapan tentang kinerja lingkungannya (Pratama, 2014).

Kepercayaan dapat timbul melalui persepsi nilai yang dilakukan konsumen dengan mengevaluasi suatu produk, sehingga persepsi nilai menjadi penentu penting dalam mempengaruhi kepercayaan pelanggan dan niat beli produk (Wulandari dan Ekawati, 2015). Persepsi nilai (perceived value) memainkan peran penting dalam mempengaruhi niat beli produk ramah lingkungan dan merupakan penentu penting dalam keduanya mempertahankan hubungan pelanggan jangka panjang dan mempengaruhi kepercayaan pelanggan (Chen and Chang, 2012).

Starbucks Corporationadalah sebuah jaringan kedai kopi dari Amerika Serikat yang bermarkas di Seattle, Washington. Starbucks adalah perusahaan kedai kopi terbesar di dunia, dengan 15.012 kedai di 44 negara (Pandri, 2011). Salah satu dari 44 negara tersebut adalah negara Indonesia. Di Indonesia sendiri jumlah gerai kopi Starbucks mengalami peningkatan dari tahun ke tahun bahkan Starbucks Coffee pada tahun 2018 menargetkan untuk membuka 60 - 70 gerai baru dengan berlokasi di Jakarta dan luar Jakarta termasuk di luar Pulau Jawa (Kontan.co.id). Jumlah gerai Starbucks CoffeeTahun 2018 di Provinsi Bali hingga saat ini sebanyak 10 gerai kopi (Starbucks.com). Perkembangan gerai Starbucks Coffee ini tidak lepas dari brand dari Starbucks Coffee itu sendiri, hal tersebut dapat dilihat dari Tabel 1.

Dilihat dari Tabel 1 produk Starbucks menempati urutan pertama dalam top brand award 2018. Bahkan angka yang diperoleh jauh melampaui pesaing pesaingnya. Brand image yang positif akan menimbulkan niat beli konsumen 
akan suatu produk (Hakim, 2017). Hasil penelitian Saputra dan Ardani (2017) menunjukkan bahwa semakin baik aktivitas green marketing yang diterapkan oleh perusahaan melalui pembuatan kemasan produk yang ramah lingkungan, pengembangan produk yang tidak membahayakan lingkungan serta tanggungjawab perusahaan terhadap masalah lingkungan maka semakin tinggi pula brand image yang tercipta.

Tabel 1.

Data Coffee Shop Berdasarkan Top Brand di Indonesia Tahun 2018

\begin{tabular}{cc}
\hline Merek & Top brand Indonesia (\%) \\
\hline Starbucks & 51,9 \\
The Coffee Bean \& Tea Leaf & 8,6 \\
Ngopi Doeloe & 1,7 \\
\hline Sumber: Topbrand-award 2018 &
\end{tabular}

Gerai Starbucks di Indonesia selain memiliki menu berbagai macam kopi seperti caffe latte, cappuccino, caffe mocha dll, Starbucks juga menyediakan makanan ringan seperti cake dan roti sebagai makanan pelengkap. Kehadiran Starbucks Coffee di Indonesia memang diterima dengan baik oleh masyarakat Indonesia, hal ini terbukti dengan mudahnya ditemukan gerai Starbucks Coffeepada pusat - pusat gerai hiburan manapun di Indonesia (Zachra, 2011).

Secara internasional Starbucks Coffee telah dikenal dan diakui sebagai salah satu green company yang peduli akan kesejahteraan petani kopi di negara negara berkembang, perusahaan yang mempedulikan pegawai, komunitas dan konsumen serta sebuah perusahaan yang kegiatan operasional bisnisnya selalu mengedepankan aktivitas yang ramah lingkungan (Neviana, 2010). StarbucksCoffee sendiri memiliki konsep green marketing atau strategi pemasaran hijau untuk menunjukkan kepedulian terhadap lingkungan. Konsep ini dituangkan dalam program global "Starbucks Shared Planet, Use Tumbler" yang bertujuan 
untuk mengajak dan mengedukasi konsumen Starbucks Coffee untuk mengubah perilaku konsumsi produk minuman Starbucks Coffeedari kemasan regular berupa gelas plastik yang hanya dapat digunakan untuk satu kali pemakaian saja, beralih ke kemasan gelas tumbler pribadi milik konsumen Starbucks Coffee yang bisa di beli di gerai - gerai kopi Starbucks pilihan konsumen dan gelas tumbler tersebut dapat digunakan untuk konsumsi produk minuman Starbucks Coffee secara berulang - ulang dan tanpa batas (Aprilisya dkk., 2017).

Tumbler Starbucks sangat aman digunakan untuk botol minum kebutuhan sehari-hari meskipun dipakai berulang kali dengan varian yang dimiliki oleh tumbler Starbucks adalah tumbler yang terbuat dari stainless steel, aluminium, serta tumblerinsert paper (pusattumbler.com). Harga tumbler Starbucks yang terbuat dari stainless steel memang sangat mahal namun sebanding dengan kualitasnya yang awet, begitu pula dengan harga tumbler Starbucks yang terbuat dari aluminium (Farahfitri,2017). Botol minumnya tidak akan meninggalkan bau apabila terkena sinar matahari. Selain itu, juga dapat menyimpan air panas. Kisaran harga tumbler Starbuck antara Rp 100.000 sampai Rp 675.000.

Penelitian sebelumnya yang dilakukan oleh Cheng and Chang (2012) menyatakan green trust mampu memediasi pengaruh green percieved value terhadap green purchase intentions. Namun penelitian lain menunjukkan berbeda, green trust tidak berperan sebagai pemediasi pengaruh green percieved value terhadap green purchase intentions. Tetapi green purchase intentions yang masih rendah ditentukan oleh banyak faktor, antara lain: belum adanya kesadaran terhadap lingkungan, belum adanya kepedulian pada lingkungan, sikap terhadap 
lingkungan yang tidak positif, belum adanya pengetahuan konsumen tentang produk hijau dan nilai yang dirasakan konsumen (green perceieved value) serta kepercayaan konsumen pada produk hijau (green trust) masih relatif rendah Paramitha dan Yasa (2015).

Kepercayaan konsumen yang semakin besar akan membuat niat beli konsumen juga tinggi, hal tersebut dapat dibuktikan dalam penelitian yang dilakukan oleh Indraswari dan Pramudana (2014). Menurut Rizanata (2014) kepercayaan pelanggan berpengaruh tidak signifikan terhadap niat beli pelanggan indomaret di Surabaya. Variabel kepercayaan tidak memiliki signifikan hubungannya dengan variabel niat pembelian hijau karena hubungan antara dua variabel independen (Irandus and Bamdad, 2014).

Prasurvei dilakukan untuk memperkuat argumentasi mengenai peran green trust memediasi pengaruh green perceived value terhadap green purchase intentions produk tumbler Starbuck On The Go di Kota Denpasar, dengan mengajukan beberapa pertanyaan yang dilakukan terhadap 30 orang di Kota Denpasar. Berdasarkan 30 orang yang diwawancara, 27 orang mengetahui produk Tumbler Starbucks dan 3 orang tidak mengetahui produk Tumbler Starbucks sehingga tidak dapat melanjutkan menjawab pertanyaan. Sebanyak 27 orang yang mengetahui produk Tumbler Starbucks, 26 orang mengatakan belum pernah melakukan pembelian Tumbler Starbucks. Sehingga dari 26 responden tersebut, peneliti menanyakan respon dari pernyataan variabel - variabel terkait yang ditunjukkan oleh Tabel 2. 
Tabel 2.

Pernyataan Pra-Survei

\begin{tabular}{|c|c|c|c|c|c|}
\hline \multirow{2}{*}{ No. } & \multirow{2}{*}{ Variabel } & \multirow{2}{*}{ Pernyataan } & \multicolumn{2}{|c|}{ Jawaban } & \multirow[t]{2}{*}{ Responden } \\
\hline & & & + & - & \\
\hline 1. & $\begin{array}{l}\text { Green perceived } \\
\text { value }\end{array}$ & $\begin{array}{l}\text { Saya memiliki pandangan } \\
\text { jika Tumbler Starbuck } \\
\text { dapat mengurangi } \\
\text { penggunaan gelas plastik } \\
\text { sekali pakai. }\end{array}$ & $\begin{array}{l}24=S S \\
2=S\end{array}$ & 0 & 26 \\
\hline 2. & Green trust & $\begin{array}{l}\text { Saya yakin jika produk } \\
\text { Tumbler adalah produk } \\
\text { yang ramah lingkungan }\end{array}$ & $\begin{array}{l}21=S S \\
3=S\end{array}$ & $2=\mathrm{TS}$ & 26 \\
\hline 3. & $\begin{array}{l}\text { Green Purchase } \\
\text { Intentions }\end{array}$ & $\begin{array}{l}\text { Saya berniat untuk membeli } \\
\text { produk Tumbler karena } \\
\text { pandangan dan keyakinan } \\
\text { bahwa produk Tumbler } \\
\text { memiliki kepedulian } \\
\text { terhadap lingkungan }\end{array}$ & $\begin{array}{l}17=\mathrm{SS} \\
7=\mathrm{S}\end{array}$ & $2=\mathrm{TS}$ & 26 \\
\hline
\end{tabular}

Jawaban setiap item diberi skor dengan interval 5, dimana $1=$ sangat tidak setuju (STS), 2 = tidak setuju (TS), 3 = cukup setuju $(\mathrm{CS}), 4=$ setuju $(\mathrm{S}), 5=$ sangat setuju (SS). Berdasarkan beberapa pernyataan yang diajukan kepada 26 orang pra survei, sebanyak 24 orang menjawab sangat setuju dan 2 orang menyatakan setuju jikaTumbler Starbuck dapat mengurangi penggunaan gelas plastik sekali pakai. Sedangkan sebanyak 21 orang menyatakan sangat setuju dan 3 orang menyatakan setuju jika produk Tumbler adalah produk yang ramah lingkungan. Namun sebanyak 2 orang merespon negatif dari pernyataan ini. Hal ini mengindikasikan variabel green perceived value dan green trust memberikan pengaruh pada niat beli konsumen pada produk Tumbler Starbuck di Kota Denpasar.

Chen and Chang (2012), menyatakan green perceived value berpengaruh positif terhadap green trust konsumen pada produk ramah lingkungan, Hal tersebut didasarkan sebuah fakta bahwa pada konsumen yang telah mengetahui informasi tentang manfaat yang akan didapat dari penggunaan suatu produk akan 
menciptakan sebuah kepercayaan dan ketertarikan terhadap produk tersebut. Perceived value sangat penting demi menimbulkan kepercayaan konsumen karena konsumen akan bergantung pada suatu produk jika harapannya terhadap kualitas, kehandalan serta kebaikan produk tersebut terpenuhi dan sesuai dengan yang diinginkan (Kamtarin, 2012).

Penelitian yang dilakukan oleh Alamsyah (2012) menemukan terdapat hubungan yang positif antara green perceived value dan green trust. Hal serupa juga dikemukakan oleh Pratama (2014), berdasarkan hasil penelitiannya yang menunjukkan bahwa green perceived value berpengaruh positif terhadap green trust konsumen pada lampu Philips LED. Green perceived value sangat penting demi menimbulkan kepercayaan konsumen karena konsumen akan bergantung pada suatu produk jika harapannya terhadap kualitas, kehandalan serta kebaikan produk tersebut terpenuhi dan sesuai dengan yang diinginkan (Kim et al., 2008). Berdasarkan dari hasil penelitian sebelumnya, maka pada penelitian ini dapat ditarik hipotesis sebagai berikut:

$\mathrm{H}_{1}$ : Green perceived value berpengaruh positif dan signifikan terhadap green trust.

Perceived value adalah seperangkat atribut yang berkaitan dengan persepsi nilai suatu produk sehingga dapat membangun efek word-of-mouth dan meningkatkan minat beli secara positif sehingga sejak perusahaan mempromosikan produknya dengan informasi yang kurang lengkap maupun klaim mengenai nilai lingkungan yang tidak benar, konsumen mulai enggan membeli produk (Chen and Chang, 2012), oleh karena itu dapat dikatakan 
perceived value saat ini memegang peranan yang lebih penting pada era lingkungan dan merupakan salah satu mempengaruhi purchase intentions. Hasil empiris dalam Yadav dan Pathak (2017) menyebutkan bahwa nilai hijau yang dirasakan secara positif terkait dengan niat pembelian hijau.

Perceived value yang buruk dapat mengakibatkan menghilangnya minat beli konsumen (Sweeney dan Soutar, 2001), dan juga sebaliknya bahwa jika konsumen merasa perceived value suatu produk tinggi maka konsumen cenderung untuk membeli produk tersebut (Chen and Chang, 2012). Dalam penelitian (Wulandari dan Ekawati, 2015) pada produk Oriflame di Kota Denpasar,persepsi nilai berpengaruh positif dan signifikan terhadap niat beli. Untuk itu mengenai masalah lingkungan saat ini green perceive value mempengaruhi green purchase intentions secara positif (Chen and Chang, 2012). Berdasarkan dari hasil penelitian sebelumnya, maka pada penelitian ini dapat ditarik hipotesis sebagai berikut:

$\mathrm{H}_{2}$ : Green perceived value berpengaruh positif dan signifikan terhadap green purchase intention

Kepercayaan merupakan salah satu faktor utama yang mempengaruhi pembelian Kamtarin (2012). Jika diangkat pada masalah lingkungan saat ini menurut Chen and Chang (2012) perusahaan cenderung terlalu membesar besarkan kinerja lingkungan produknya yang tidak sesuai harapan konsumen, sehingga konsumen enggan untuk mempercayai perusahaan lagi. Pengaruh positif yang signifikan antara kepercayaan terhadap niat beli menunjukkan pentingnya reputasi logis produk, keamanan dan kenyamanan dalam menggunakan produk, manfaat produk serta integritas, secara keseluruhan itu merupakan aspek 
Ni Luh Putu Martha Pradnyadewi, PeranGreen Trust...

kepercayaan pengaruh kuat dalam mendorong niat pembelian konsumen Terenggana et al. (2013).

Kepercayaan konsumen yang semakin besar akan membuat niat beli konsumen juga tinggi, hal tersebut dapat dibuktikan dalam penelitian yang dilakukan oleh Indraswari dan Pramudana (2014). Chen (2010) berpendapat bahwa kepercayaan hijau memiliki pengaruh signifikan terhadap perilaku pembelian konsumen di era lingkungan dimana dampak dari kepercayaan hijau pada niat pembelian hijau dapat ditentukan melalui penilaian konsumen tentang kepercayaan jangka panjang terhadap produk hijau karena berdampak positif terhadap lingkungan.Purchase intention dipengaruhi oleh kepercayaan konsumen, jika konsumen memiliki kepercayaan yang baik terhadap produsen, perusahaan, maupun produk dan jasa maka, konsumen akan memiliki minat beli yang tinggi (Chen and Chang, 2012). Dengan demikian green trustakan mempengaruhi consumer purchase behaviour. Berdasarkan dari hasil penelitian sebelumnya, maka pada penelitian ini dapat ditarik hipotesis sebagai berikut:

$\mathrm{H}_{3}$ : Green trust berpengaruh positif dan signifikan terhadap green purchase intention

Penelitian yang dilakukan oleh Dehghanan dan Bakhshandeh (2014) menunjukkan hasil bahwa green trust memediasi pengaruh green perceivedvalue terhadap green purchase intention pada produk ramah lingkungan di Iran, hal tersebut dikarenakan semakin banyaknya informasi yang didapat oleh konsumen mengenai manfaat suatu produk yang pada gilirannya akan menimbulkan kepercayaan terhadap produk sehingga akhirnya dapat mempengaruhi perilaku pembelian konsumen pada produk tersebut. Kepercayaan hijau memiliki efek 
mediasi antara nilai yang dipersepsikan hijau dan niat membeli merek hijau (Isa et al., 2013).

Penelitian sebelumnya yang dibuktikan oleh Chen and Chang (2012) yang menyebutkan bahwa perusahaan perlu meningkatkan kepercayaan hijau pelanggan mereka, karena terdapat efek mediasi positif signifikan pada kepercayaan hijau sehingga perusahaan dapat membangun kepercayaan hijau dari pelanggan mereka untuk meningkatkan hubungan antara nilai yang dirasakan dan niat pembelian hijau. Kepercayaan mampu memediasi pengaruh persepsi nilai terhadap niat beli pada produk Oriflame di Kota Denpasar dengan semakin tinggi persepsi nilai yang di ungkapkan maka semakin tinggi kepercayaan yang mana hal ini akan meningkatkan niat beli produk (Wulandari dan Ekawati, 2015)

$\mathrm{H}_{4}$ : Green trustsecara positif dan signifikan memediasi pengaruh green perceived value terhadap green purchase intention.

\section{METODE PENELITIAN}

Kota Denpasar dipilih sebagai lokasi untuk dilakukannya penelitian dengan pertimbangan Kota Denpasar merupakan daerah mobilitas penduduk tertinggi di Bali. Masyarakat Kota Denpasar menduduki posisi tertinggi rata - rata konsumsi per kapita seprovinsi Bali pada tahun 2017 sebesar Rp 1.966.789 per bulan serta menduduki posisi kedua tertinggi pendapatan perkapita pada tahun 2017 sebesar Rp 1.008.710.712 (bps.go.id,). Keadaan dari masyarakat Kota Denpasar tersebut memungkinkan terjadinya pengeluaran yang tinggi akan konsumsi makanan dan minuman, sehingga lebih mudah untuk menemukan responden. 
Variabel eksogen dalam penelitian ini adalah green perceived value (X). Variabel endogen dalam penelitian ini adalah green purchase intentions (Y). Variabel mediasi dalam penelitian ini adalah green trust $(\mathrm{M})$.

\section{Tabel 3.}

Indikator Variabel Penelitian

\begin{tabular}{|c|c|c|c|}
\hline No & Variabel & Indikator & Sumber \\
\hline 1 & $\begin{array}{l}\text { Green Perceived } \\
\text { Value (X) }\end{array}$ & $\begin{array}{l}\text { 1). Good Value (X1) } \\
\text { 2). Meet the expextacions (X2) } \\
\text { 3). Environmental concern (X3) } \\
\text { 4). Environmental Friendly (X4) } \\
\text { 5). Environmental Benefit (X5) }\end{array}$ & $\begin{array}{l}\text { Chen and Chang } \\
\text { (2012) }\end{array}$ \\
\hline 2 & Green Trust (M) & $\begin{array}{l}\text { 1). Keyakinan konsumen pada sebuah } \\
\text { produk(M1) } \\
\text { 2). Keyakinan konsumen akan nama } \\
\text { baik (reputasi)(M2) } \\
\text { 3). Keyakinan konsumen akan kinerja } \\
\text { produk terhadap lingkungan(M3) } \\
\text { 4). Keyakinan konsumen akan } \\
\text { komitmen produk terhadap } \\
\text { perlindungan lingkungan(M4) }\end{array}$ & Chen et al (2015) \\
\hline 3 & $\begin{array}{l}\text { Green Purchase } \\
\text { Intentions }(\mathrm{Y})\end{array}$ & $\begin{array}{l}\text { 1). Niat beli konsumen karena } \\
\text { kepedulian produk terhadap } \\
\text { lingkungan(Y1) } \\
\text { 2). Ketertarikan kosumen } \\
\text { menggunakan produk karena } \\
\text { performa produk terhadap } \\
\text { lingkungan(Y2) } \\
\text { 3). Keinginan konsumen membeli } \\
\text { produk karena dapat melestarikan } \\
\text { lingkungan(Y3) }\end{array}$ & $\begin{array}{l}\text { Chen and Chang } \\
\text { (2012) }\end{array}$ \\
\hline
\end{tabular}

Sumber: Data diolah, 2018

Populasi dalam penelitian ini adalah seluruh masyarakat Kota Denpasar yang menempuh minimal pendidikan SMA/SMK dalam hal ini jumlahnya tidak dapat diidentifikasi serta sudah mengetahui produk Tumbler Starbucks on the go namun dalam hal ini belum pernah melakukan pembelian terhadap produk tersebut. Penelitian ini menggunakan 12 indikator sehingga dengan menggunakan estimasi jumlah minimal responden sebanyak 60 orang dan maksimal 120 orang. 
Karena keterbatasan peneliti, maka peneliti sendiri menggunakan sampel sebanyak 100 responden.

Metode penentuan sampel yang digunakan pada penelitian ini adalah metode non probability sampling dengan teknik pengambilan sampel yang digunakan dalam penelitian ini adalah purposive sampling, yaitu sampel ditentukandengan pertimbangan tertentu.

Data dalam penelitian ini dikumpulkan melalui kuesioner. Metode pengumpulan data berupa penyebaran kuesioner yang secara langsung disebarkan oleh peneliti. Kuesioner terdiri dari pertanyaan terbuka yaitu identitas diri responden dan pertanyaan tertutup yaitu pernyataan - pernyataan yang telah disediakan dan jawaban yang diberikan dibatasi.

Teknik analisis statistik inferensial dalam penelitian ini adalah teknik analisis jalur (Path Analysis). Analisis jalur digunakan untuk menentukan pola hubungan antara tiga atau lebih dan tidak dapat digunakan untuk mengkonfirmasi atau menolak hipotesis.

Pengujian hipotesis mediasi dapat dilakukan dengan prosedur yang dikembangkan oleh Sobel (1982) dan dikenal dengan Uji Sobel (Sobel Test). Uji Sobel digunakan dengan menguji kekuatan pengaruh tidak langsung variabel green perceived value (X) terhadap variabel green purchase intentions (Y) melalui variabel green trust (M).

\section{HASIL PENELITIAN DAN PEMBAHASAN}


Perhitungan koefisien jalur dilakukan dengan analisis regresi melalui software (SPSS) for Windows diperoleh dari hasil yang ditunjukkan pada Tabel 4.13 dan Tabel 4.

Berdasarkan hasil analisis jalur substruktur 1 seperti yang disajikan pada Tabel 4, maka persamaan strukturalnya adalah sebagai berikut:

$\mathrm{M}=\beta_{1} \mathrm{X}+\mathrm{e}_{1}$

$\mathrm{M}=0,713 \mathrm{X}+\mathrm{e}_{1}$

Tabel 4.

Hasil Analisis Jalur Persamaan Regresi 1

\begin{tabular}{lcccc}
\hline \multicolumn{1}{c}{ Variabel } & Standardized Coefficients & Std. Error & t hitung & Sig. uji t \\
\hline (Constant) & & 0,285 & 4,874 & 0,000 \\
Green Perceived Value (X) & 0,713 & 0,68 & 10,063 & 0,000 \\
R Square & 0,508 & & & \\
F Statistik & 101,257 & & & \\
Signifikansi Uji F & 0,000 & & & \\
\hline Sumber: Data diolah, 2018 & & &
\end{tabular}

Sumber: Data diolah, 2018

Berdasarkan hasil analisis pengaruh pengaruh green perceived value terhadap green trust diperoleh nilai Sig t sebesar 0,000 dengan nilai koefisien beta sebesar 0,713 Nilai Sig. t 0,000 $\leq 0,05$ mengindikasikan bahwa $\mathrm{H}_{0}$ ditolak dan $\mathrm{H}_{1}$ diterima. Hasil ini mempunyai arti bahwa green perceived value berpengaruh positif dan signifikan terhadap green trust.

Berdasarkan hasil analisis jalur substruktural 2 seperti yang disajikan pada tabel 5, maka persamaan strukturalnya adalah sebagai berikut:

$$
\begin{aligned}
& Y=\beta_{2} X+\beta_{3} M+e_{1} \ldots \ldots \ldots \\
& Y=0,270 X+0,340 M+e_{2}
\end{aligned}
$$

Tabel 5.

Hasil Analisis Jalur Persamaan Regresi 2

\begin{tabular}{lcccc}
\hline \multicolumn{1}{c}{ Variabel } & Standardized Coefficients & Std. Error & t hitung & Sig. uji t \\
\hline (Constant) & & 0,379 & 4,355 & 0,000 \\
\hline
\end{tabular}




\begin{tabular}{lcccc}
\hline Green Perceived Value $(\mathrm{X})$ & 0,270 & 0,116 & 2,260 & 0,026 \\
Green Trust $(\mathrm{M})$ & 0,340 & 0,120 & 2,843 & 0,005 \\
R Square & 0,319 & & & \\
F Statistik & 22,726 & & & \\
Signifikansi Uji F & 0,000 & & & \\
\hline Subir: Dat din
\end{tabular}

Sumber: Data diolah, 2018

Berdasarkan hasil analisis pengaruh pengaruh green perceived value terhadap green purchase intentions diperoleh nilai Sig t sebesar 0,000 dengan nilai koefisien beta sebesar 0,270 Nilai Sig. t 0,026 $\leq 0,05$ mengindikasikan bahwa $\mathrm{H}_{0}$ ditolak dan $\mathrm{H}_{1}$ diterima. Hasil ini mempunyai arti bahwa green perceived value berpengaruh positif dan signifikan terhadap green purchase intentions.

Berdasarkan hasil analisis pengaruh pengaruh green trust terhadap green purchase intentions diperoleh nilai Sig t sebesar 0,000 dengan nilai koefisien beta sebesar 0,340 Nilai Sig. t 0,005 $\leq 0,05$ mengindikasikan bahwa $\mathrm{H}_{0}$ ditolak dan $\mathrm{H}_{1}$ diterima. Hasil ini mempunyai arti bahwa green trust berpengaruh positif dan signifikan terhadap green purchase intentions.

Berdasarkan model substruktur 1 dan model substruktur 2, maka dapat disusun model diagram jalur akhir. Sebelum menyusun model diagram jalur akhir, terlebih dahulu dihitung nilai standar error sebagai berikut:

$$
\begin{aligned}
& \mathrm{e}_{1}=\sqrt{1-R^{2}} \ldots \ldots \ldots \ldots \ldots \ldots \ldots \ldots \ldots \ldots \ldots \ldots \\
& \mathrm{e}_{1}=\sqrt{1-K 1^{2}}=\sqrt{1-0,508}=0,702 \\
& \mathrm{e}_{2}=\sqrt{1-K 2^{2}}=\sqrt{1-0,319}=0,825
\end{aligned}
$$

Berdasarkan perhitungan pengaruh error (e), didapatkan hasil pengaruh error $\left(e_{1}\right)$ sebesar 0,702 dan pengaruh error $\left(e_{2}\right)$ sebesar 0,825 .

Hasil koefisien determinasi total adalah sebagai berikut: 


$$
\begin{aligned}
\mathrm{R}^{2} \mathrm{~m} & =1-\left(\mathrm{Pe}_{1}\right)^{2}\left(\mathrm{Pe}_{2}\right)^{2} \ldots \ldots \\
& =1-(0,702)^{2}(0,825)^{2} \\
& =1-(0,493)(0,681) \\
& =1-0,336 \\
& =0,664
\end{aligned}
$$

Nilai determinasi total sebesar 0,664 mempunyai arti bahwa sebesar 66,4 persen variasi green purchase intentions dipengaruhi oleh variasi green perceived value dan variasi green trust, sementara sisanya sebesar 33,6 persen dijelaskan oleh faktor lain.

Tabel 6.

Pengaruh Langsung, Pengaruh Tidak Langsung serta Pengaruh Total Green Perceived Value (X), Green Trust (M), dan Green Purchase Intentions (Y)

\begin{tabular}{lccc}
\hline \multicolumn{1}{c}{ Pengaruh Variabel } & $\begin{array}{c}\text { Pengaruh } \\
\text { Langsung }\end{array}$ & $\begin{array}{c}\text { Pengaruh Tidak } \\
\text { Langsung Melalui } \\
\text { Green Purchase } \\
\text { Intentions }(\mathbf{M})=\left(\boldsymbol{\beta}_{\mathbf{1}} \mathbf{x} \boldsymbol{\beta}_{3}\right)\end{array}$ & $\begin{array}{c}\text { Pengaruh } \\
\text { Total }\end{array}$ \\
\hline $\begin{array}{l}\text { Green perceived value }(\mathrm{X}) \\
\begin{array}{l}\text { Green trust }(\mathrm{M}) \\
\text { Green perceived value }(\mathrm{X}) \text { Green } \\
\text { purchase intentions }(\mathrm{Y})\end{array}\end{array}$ & 0,270 & - & 0,713 \\
$\begin{array}{l}\text { Green trust }(\mathrm{M}) \text { Gren purchase } \\
\text { intentions }(\mathrm{Y})\end{array}$ & 0,340 & 0,244 & 0,514 \\
\hline Sumber: Data diolah, 2018 & & - & 0,340 \\
\hline
\end{tabular}

Uji Sobel digunakan dengan menguji kekuatan pengaruh tidak langsung variabel green perce aplikasi Microsoft Excel 2010. Bila nilai kalkulasi Z lebih besar dari 1,96 (dengan tingkat kepercayaan 95 persen), maka variabel mediator dinilai secara signifikan memediasi hubungan antara variabel endogen dan variabel eksogen.

$\mathrm{Sa} 2 \mathrm{~b}=\sqrt{\mathrm{a}^{2} \mathrm{Sb}^{2}+\mathrm{b}^{2} \mathrm{Sa}^{2}+\mathrm{Sa}^{2} \mathrm{Sb}^{2}}$

Keterangan:

$$
\begin{aligned}
& \mathrm{a}=0,713 \\
& \mathrm{Sa}=0,068 \\
& \mathrm{~b}=0,340
\end{aligned}
$$




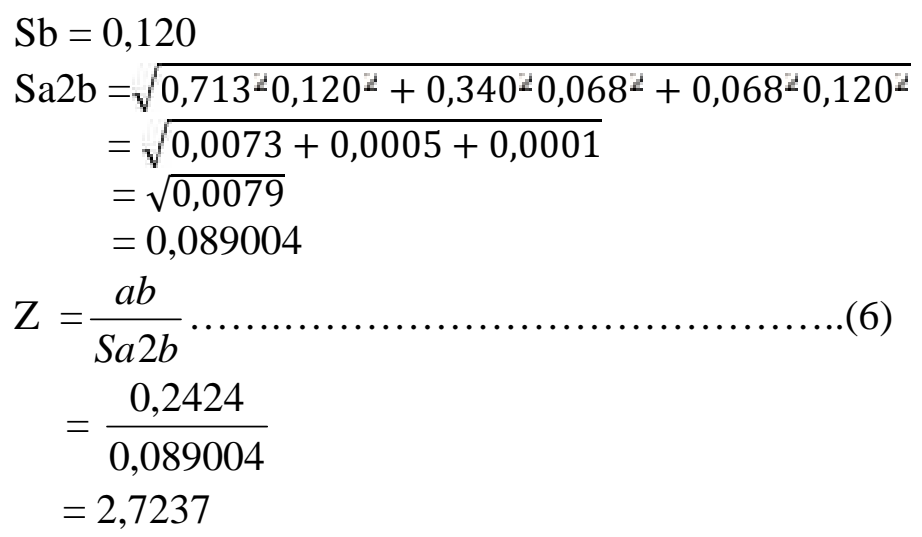

Berdasarkan hasil Uji Sobel dalam penelitian ini menunjukkan bahwa hasil tabulasi $\mathrm{Z}=2,7237>1,96$ dengan tingkat signifikansi $0,000<0,05$ yang berarti variabel mediasi yakni green trust dinilai secara signifikansi mampu memediasi pengaruh green perceived value terhadap green purchase intentions produk Tumbler Starbucks On The Go Di Kota Denpasar.

Adapun tujuan dilakukannya penelitian ini adalah untuk mengetahui pengaruh green perceived value terhadap green trust konsumen. Berdasarkan hasil olah data diperoleh nilai koefisien beta positif sebesar 0,713 dengan tingkat signifikansi sebesar 0,000 (kurang dari 0,05 ) yang artinya $\mathrm{H}_{1}$ diterima. Hal ini mengindikasikan bahwa variabel green perceived value secara positif dan signifikan berpengaruh terhadap variabel green trust. Hasil ini berarti bahwa semakin baikgreen perceived value yang dimiliki konsumen pada suatu produk maka akan semakin tinggi pula green trust yang dirasakan konsumen pada produk tersebut.

Hasil penelitian ini senada dengan beberapa hasil penelitian - penelitian sebelumnya yang telah dilakukan oleh Chen and Chang (2012), Kamtarin (2012), Alamsyah (2012), Pratama (2014) serta penelitian yang dilakukan oleh Kim et 
al.(2008) menunjukkan hasil yang positif dan signifikan antara pengaruh green perceived value terhadap green trust konsumen.

Adapun tujuan dilakukannya penelitian ini adalah untuk mengetahui pengaruh green perceived value terhadap green purchase intentions konsumen. Berdasarkan hasil olah data diperoleh nilai koefisien beta positif sebesar 0,263 dengan tingkat signifikansi sebesar 0,026 (kurang dari 0,05) yang artinya $\mathrm{H}_{1}$ diterima. Hal ini mengindikasikan bahwa variabel green perceived value secara positif dan signifikan berpengaruh terhadap variabel green purchase intentions. Hasil ini berarti bahwa semakin baik green perceived value yang dimiliki konsumen pada suatu produk maka akan semakin tinggi pula green purchase intentions konsumen pada produk tersebut.

Hasil penelitian ini mendukung beberapa hasil penelitian - penelitian sebelumnya yang telah dilakukan oleh Chen and Chang (2012), Yadav dan Pathak (2017), (Sweeney dan Soutar, 2001) serta penelitian yang dilakukan oleh Wulandari dan Ekawati (2015) menunjukkan hasil yang positif dan signifikan antara pengaruh green perceived value terhadap green purchase intentions konsumen.

Penelitian ini bertujuan untuk mengetahui pengaruh green trust terhadap green purchase intentions konsumen. Berdasarkan hasil olah data diperoleh nilai koefisien beta positif sebesar 0,340 dengan tingkat signifikan sebesar 0,005 (kurang dari 0,05) yang artinya $\mathrm{H}_{1}$ diterima. Hal ini mengindikasikan bahwa variabel green trust secara positif dan signifikan berpengaruh terhadap variabel green purchase intentions konsumen di Kota Denpasar. Hasil ini berarti bahwa 
semakin tinggi green trust yang ditunjukkan oleh konsumen terhadap suatu produk maka akan semakin tinggi pula green purchase intentions konsumen untuk melakukan pembelian produk Tumbler StarbucksOn The Go di perusahaan tersebut.

Hasil penelitian ini sesuai dengan hasil penelitian - penelitian sebelumnya yang telah dilakukan oleh Terenggana et al. (2013), Indraswari dan Pramudana (2014), Chen (2010) serta penelitian yang dilakukan oleh Chen and Chang (2012) menunjukkan hasil yang positif dan signifikan antara pengaruh green perceived value terhadap green purchase intentions konsumen.

Pengujian hipotesis pada peran green trust memediasi pengaruh green perceived value terhadapa green purchase intentions dengan menggunakan Uji Sobel menunjukkan peran green trust secara signifikan memediasi pengaruh green perceived value terhadap green purchase intentions dengan hasil $\mathrm{Z}$ sebesar 2,7237 > 1,96 dengan tingkat nilai Sig 0,000 $<0,05$, dengan demikian hipotesis keempat dalam hal ini diterima. Hasil penelitian sejalan dengan penelitian sebelumnya yang dilakukan oleh Dehghanan dan Bakhshandeh (2014), Isa et al.(2013), Chen and Chang (2012) serta penelitian yang dilakukan oleh Wulandari dan Ekawati (2015) menunjukkan hasil bahwa green trust dapat memediasi pengaruh green perceived value terhadap green purchase intentions pada produk Tumbler Starbucks On The Go di Kota Denpasar.

Melalui adanya green trust yang tinggi dari konsumen terhadap produk Tumbler Starbucks On The Go mengimplikasikan green perceived value yang dirasakan konsumen berhasil meningkatkan green purchase intentions konsumen 
terhadap Tumbler Starbucks On The Go sebagai salah satu aksi sadar dan peduli terhadap kelestarian lingkungan dengan tujuan untuk mengurangi penggunaan gelas plastik regular yang dapat mencemari lingkungan. Sehingga dapat beralih ke penggunaan Tumbler yang lebih efisien.

Implikasi hasil penelitian ini menekankan pada manfaat nyata dari hasil penelitian untuk mendorong perusahaan - perusahaan yang baru berkembang dan khususnya perusahaan - perusahaan yang telah memiliki penilaian yang positif dimata masyarakat agar mampu memiliki daya saing yang lebih kuat di pasar dan tetap mampu meningkatkan kepercayaan masyarakat terhadap produknya yaitu salah satunya dengan cara memasarkan produk dengan konsep ramah lingkungan. Menggunakan konsep - konsep ramah lingkungan dalam memasarkan suatu produk akan dapat menciptakan nilai persepsi yang positif dimata konsumen dan menumbuhkan kepercayaan terhadap produk ramah lingkungan (green trust). Sehingga memunculkan niat konsumen untuk menggunakan produk ramah lingkungan tersebut. Beberapa implikasi strategis dari hasil penelitian yaitu:

Adanya persepsi konsumen mengenai produk Tumbler Starbucks On the Go yang dapat membantu menjaga kelestarian lingkungan maka pihak manajemen tetap melakukan penerapan green marketingdengan cara tetap memproduksi produk ramah lingkungan seperti contohnya Tumbler. Hal inidapat lebih memberikan komitmen perlindungan lingkungan dimata konsumen sebagai salah satu perusahaan dengan dengan predikat green company yang telah diakui di kancah bisnis internasional. Penerapan green marketing produk Tumbler Starbucks ini akan meningkatkan kinerja lingkungan produknya untuk semakin 
menarik kalangan konsumen yang perduli akan dampak terhadap lingkungan atas produk yang dikonsumsinya.

Terbukti dari adanya green trust secara positif diberikan oleh konsumen mampu mempengaruhi munculnya green purchase intentions konsumen untuk membeli produk Tumbler Starbucks On The Go yang merupakan suatu bentuk terobosan baru yang dihadirkan oleh Starbucks Coffe dan dirasa konsumen melalui hasil kuesioner. Konsumen memiliki keyakinan akan reputasi yang baik berkaitan dengan produk Tumbler Starbuck yang ramah lingkungan. Sehingga manajemen Starbuck harus tetap menjaga reputasi tersebut. Reputasiyang baik akan produk ini akan berpengaruh pula terhadap keinginan untuk mencoba membeli Tumbler Starbucks On The Go karena manfaat yang adadalam produk tersebut disamping mengingat ketatnya persaingan bisnis dengan konsep ramah lingkungan yang tidak hanya dilakukan oleh Starbucks Coffe.

Beberapa keterbatasan penelitian yang dapat ditarik dari penelitian ini adalah ruang lingkup serta sampel penelitian dari penelitian ini sangat terbatas yang menyebabkan hasil penelitian tidak dapat digeneralisasi untuk konsumen produk ramah lingkungan di luar wilayah Kota Denpasar.

Mengingat penelitian ini dilakukan dalam titik waktu tertentu sedangkan lingkungan setiap saat bisa berubah, yang menyebabkan penelitian ini penting untuk dilakukan kembali.

\section{SIMPULAN DAN SARAN}

Berdasarkan hasil pembahasan penelitian yang telah dilakukan, maka dapat disimpulkan bahwa green perceived value berpengaruh positif dan signifikan 
terhadap green trust. Hasil ini berarti bahwa semakin baik nilai persepsi konsumen tentang kepedulian lingkungan yang diterapkan oleh Starbucks Coffeepada produk Tumbler maka akan semakin meningkat pula kepercayaan konsumen tentang kepedulian lingkungan yang diterapkan oleh Starbucks Coffeepada produk Tumbler.

Green perceived value berpengaruh positif dan signifikan terhadap green purchase intentions. Hasil ini berarti bahwa semakin baik nilai persepsi konsumen tentang kepedulian lingkungan yang diterapkan oleh Starbucks Coffeepada produk Tumbler maka akan semakin meningkat pula niat beli konsumen pada produk ramah lingkungan yang diterapkan oleh Starbucks Coffeepada produk Tumbler.

Green trust berpengaruh positif dan signifikan terhadap green purchase intentions. Hasil ini berarti bahwa semakin baik kepercayaan konsumen tentang kepedulian lingkungan yang diterapkan oleh Starbucks Coffee pada produk Tumbler maka akan semakin meningkat pula niat beli konsumen pada produk ramah lingkungan yang diterapkan oleh Starbucks Coffeepada produk Tumbler.

Green trust secara signifikan memediasi hubungan antara green perceived value terhadap green purchase intentions produk Tumbler Starbucks On The Go di Kota Denpasar. Hal ini berarti bahwa green trust konsumen yang baik terhadap Tumbler Starbucks Coffeemampu memperkuat pengaruh persepsi konsumen terhadap green purchase intentionsTumbler Starbucks Coffee tersebut.

Saran yang dapat diberikan berdasarkan kesimpulan yang didapat adalah untuk meningkatkan Green Perceived Value konsumen di Kota Denpasar, Sebaiknya Perusahaan Starbuck Coffe lebih meningkatkan kinerja lingkungan 
produk Tumbler Starbuck On The Go agar sesuai bahkan melebihi harapan para konsumen di Kota Denpasar.

Starbuck Coffe harus meningkatkan keyakinan dari konsumen akan produk Tumbler Starbuck yang memiliki kinerja yang baik terhadap lingkungan dengan tetap gencar membagikan informasi dari manfaat menggunakan Tumblersehingga konsumen semakin yakin dari kinerja lingkungan yang dilakukan perusahaan serta berdampak positif bagi kelestarian lingkungan.

Dengan tetap gencar melakukan promosi green marketing maka konsumen akan memiliki keinginan untuk mengetahui lebih tentang produk ramah lingkungan Tumbler Starbucks On The Go.

Penelitian di masa yang akan datang perlu memepertimbangkan penggunaan variabel lain yang dapat mempengaruhi green purchase intentions untuk produk produk ramah lingkungan atau green product misalnya saja seperti variabel perilaku konsumen lainnya, variabel demografi dan lain sebagainya sehingga mampu menganalisis secara lebih lanjut factor - factor yang memiliki pengaruh terhdap green purchase intentions.

Bagi peneliti selanjutnya diharapkan dapat memperluas cakupan wilayah penelitian misalnya dengan mengambil lokasi di seluruh Bali atau wilayah selain Kota Denpasar atau Indonesia.

\section{REFERENSI}

Alamsyah, Doni Purnama. (2012). Green Marketing Strategy: Hubungan Green Perceived Value Dan Green Trust. Jurnal Manajemen, 3(2), hal. 56-72.

Aprilisya, Ni Putu Eka, Ni Nyoman Kerti Yasa dan I Gusti Ayu Ketut Giantari. (2017). Peran Sikap Memediasi Pengaruh Pemasaran Hijau Terhadap Niat 
Beli Produk Ramah Lingkungan. E - Jurnal Manajemen Unud, 6(4), hal. 1701-1728.

Ariyanti, Kurnia dan Sri Setyo Iriani. (2014). Pengaruh Persepsi Nilai dan Persepsi Risiko Terhadap Niat Beli Kosmetik Organik. Jurnal Ilmu Manajemen, 2(4), hal. 1186-1196.

Balawera, Asrianto. 2013. Green marketing dan corporate social responsibility Pengaruhnya Terhadap Keputusan Pembelian Konsumen Melalui Minat Membeli Produk Organik di Freshmart kota manado. Jurnal Riset Ekonomi, Manajemen, Bisnis dan Akuntasi, 1(4), hal. 2117-2129.

Bps.go.id. https://bali.bps.go.id/linkTableDinamis/view/id/7. Diakses pada 28 Juli (2018).

Bps.go.id.https://bali.bps.go.id/dynamictable/2018/02/02/213/pendapatan-aslidaerah-kabupaten-kota-se-bali-2000-2016.html. Diakses pada 28 Juli (2018).

Chen, Y. S. (2010). The driver of green brand equity:green brand image, green satisfaction, and greentrust. Journal of Business Ethics, 9(3), hal. 307-319.

Chen, Yu-Shan and Ching-Hsun Chang. (2012). Enhance Green Purchase Intetions The Roles of Green Perceived Value, Green Perceived Risk, and Green Trust. Management Decision, 50(3), hal. 502-520.

Chen, Lin, Weng. (2015). The Influence Of Environmental Friendliness On Green Trust: The Mediation Effect Of Green Satisfaction And Green Perceived Quality. Journal Suistainability, 7(3), hal. 10135-10152.

Cherian, J., and Jacob, J. (2012). Green Marketing: A Study of Consumers' Attitude Towards Environment Friendly Products. Asian Social Science, 8(12), hal. 1911-2025.

Dehghanan, H., and Bakhshandeh, G. (2014). Theimpact of green perceived value and greenperceived risk on green purchase behavior ofIranian consumers. International Journal ofManagement and Humanity Sciences, 3(2), hal.1349-1357.

Efriandi, Iwan. (2013). Kualitas Pelayanan dan Kepercayaan Nasabah (Studi pada Nasabah Tabungan PT Bank Aceh di Kota Blangpidie). Jurnal Ekonomi Manajemen Dan Bisnis, 11(2), hal. 171-182.

Farahfitri. (2017). Pemburu Diskon: Kisah Saya Dengan Starbuck. https://farahfitriani.wordpress.com/2017/03/09/pemburu-diskon-kisah-sayadengan-starbucks/. Diakses pada 31 Juli 2018.

Hakim, Arif Rachman. (2017). Pengaruh Brand Image Terhadap Minat Beli Konsumen Pada Bimbel Tridaya Bandung. E - Proceeding of Applied Science, 3(2), hal. 480-486.

Indraswari, Ni Md Mahadewi dan Komang Agus Satria Pramuda. (2014). Pengaruh Kredibilitas Celebrity Endorser Dan Kewajaran Harga terhadap 
Niat Beli Konsumenn Wanita Pada Online Shop Produk Pakaian. http://ojs.unud.ac.id/index.php/Manajemen/article/viewFile/7501/6366 Diunduh tanggal 17, bulan Juli, tahun 2018.

Isa, Salmi Mohd, Chew Kun Lim and Phaik Nie Chin. (2017). Green Purchase Intention of Laundry Detergent Powder in Presence of Eco - Friendly Brand. Global Business and Management Research: An International Journal, 9(4), hal. 128-143.

Kamtarin, Milad.,(2012), The Effect of Electronic Word of Mouth, Trust and Perceived Value on Behavioral Intention from the Perspective of Consumers. International Journal of Academic Research in Economics and Management Sciences, 1(4), hal. 56-66.

Kim, Changsu Zhao, Weihong, Yang Kyung Hoon. (2008). An Empirical Study On Integrated Framework Of E-CRM In Online Shopping: Evaluating The Relationships Among Perceived Value, Satisfaction, And Trust Based On Customers Perpectives. Journal Of Electronic In Organizations, 6(3), hal. 119.

Kontan.co.id. Sampai Mei (2018), Starbucks Buka 25 Gerai Baru. https://industri.kontan.co.id/news/sampai-mei-2018-starbucks-buka-25gerai-baru. Diakses pada 28 Juli 2018

Kotler, Philip. dan Gary Armstrong. (2006). Prinsip - Prinsip Pemasaran. Penerbit Erlangga.

Liang, Q., and Chaipoopirutana, S. (2014). A study offactors affecting customer's attitude towardintention to purchase green electronic products at an it mall in Beijing, China. InternationalConference on Business, Law and CorporateSocial Responsibility, 1(2), hal. 45-49.

Mahendra, I Made Gilang dan Eka Sulistyawati. (2017). Pengaruh Green Brand Image dan Green Perceived Value Terhadap Green Trust dan Green Brand Equity. E-Jurnal Manajemen Unud, 6(7), hal. 3850-3877.

Neviana. (2010). Triple Botton Line: Lebih Dari Sekedar Profit. http://swa.co.id/my-article/triple-bottom-line-lebih-dari-sekadar-profit. Diakses pada 25 Pebruari 2018.

Pandri. (2011). Sejarah Berdiri Minuman Starbucks. http://pandri16.blogspot.com/2011/11/sejarah-berdiri-perusahaan-starbucks.html. Diakses pada 28 Juli 2018.

Pratama, M. A. (2014). Profil green consumersIndonesia: identifikasi segmen dan faktor-faktoryang mempengaruhi perilaku pembelian greenproducts. Jurnal Ilmiah Mahasiswa UniversitasSurabaya, 3(1), hal. 13-24.

Pusattumbler.com. Variasi Harga Tumbler Starbuck Daei Kedai Starbuck Yang Terkenal. http://pusattumbler.com/variasi-harga-tumbler-starbucks-darikedai/. Diakses pada 31 Juli (2018) 
Putri, Putu Tara Ayu Paramita., I Putu Gde Sukaatmaja dan Ni Wayan Suprapti. (2014). Peran Sikap Dalam MemediasiHubungan Pengetahuan Tentang Lingkungan Dengan Niat Membeli Produk Hijau PendinginUdara Merek LG. E-Jurnal Manajemen Unud, 2(5), hal 558-574.

Rizanata, Muhamad Fahmi. (2014). Pengaruh Kepercayaan Pelanggan terhadap Word Of Mouth, Niat Beli Dan Retensi Pelanggan Gerai Indomaret di Surabaya. Journal Of Bussiness And Banking, 4(1), hal. 31-42

Rizwan, Muhammad, Usman Mahmood, Ahmad Siddiqui, and Arham Tahir. (2014). An Empirical Study about Green Purchase Intentions. Journal of Sociological Research, 5(1), hal. 1948-5468.

Saputra, I Gusti Putu Aditya dan I Gusti Agung Ketut Sri Ardani. (2017). Peran Brand Image Dalam Memediasi Pengaruh Green Marketing Terhadap Corporate Reputation. E - Jurnal Manajemen Unud, 6(1), hal. 87-115.

Starbucks.com. Diakses pada 28 Juli (2018).

Suprapti, Ni Wayan Sri. (2010). Prilaku Konsumen, Pemahaman Dasar dan Aplikasinya Dalam Strategi Pemasaran.Bali : Udayana University Press.

Sweeney, Jillian C., Geoffrey N. Soutar. (2001). Consumer Perceived Value: The development of a multiple item scale. Journal of Retailing, 7(7), hal. 203220.

Terenggana, Candra Astra, Henky Supit, dan Christina Widya Utami. (2013). Effect Of Volue, Consumer Trust and Attitudes Towards Intention Buy Environmentally Friendly Air Conditioners Product In South Sumatera. Academic Research International, 4(3), hal. 323-335.

Top Brand Coffe Shop Indonesia. http://www.topbrand-award.com/top-brandsurvey/survey-result/top_brand_index_2018_fase_2. Diakses pada 28 Juli (2018).

Wulandari, Ni Luh Putu Sari dan Ni Wayan Ekawati. (2015). Peran Kepercayaan Dalam Memediasi Persepsi Nilai Terhadap Niat Beli Produk Ramah Lingkungan. E-Jurnal Manajemen Unud, 4(7), hal. 2095-2109.

Yadav, Rambalak dan Govind S Pathak. (2017). Determinants of Consumers' Green Purchase Behavior in aDeveloping Nation: Applying and Extending the Theory of PlannedBehavior. Ecological Economics, 1(34), hal. 114-122.

Zachra, Ellyzar. (2011). Starbucks: Rumah Ketiga Bagi Penggila Kopi, http://swa.co.id/listed-articles/star-bucks-rumah-ketiga-bagi-penggila-kopi. Diakses pada 25 Pebruari 2018 